\author{
포유모돈 사료에 코코넛 분말지방 첨가가 모돈의 생산성 및 \\ 모유성상에 미치는 효과 \\ 김효진 • 조진호 • 진영걸 • 유종상 • 신승오 • 황 염 • 김인호 \\ 단국대학교 동물자원과학과
}

\title{
Effects of Dietary Coconut Fat Powder Supplementation on Performance and Milk Characteristics in Lactating Sow
}

\author{
H. J. Kim, J. H. Cho, Y. J. Chen, J. S. Yoo, S. O. Shin, Y. Huang and I. H. Kim \\ Department of Animal Resource \& Science, Dankook University
}

\begin{abstract}
A total of thirty sows (LandracexYorkshire) were used to determine the effects of dietary coconut fat powder supplementation on performance, nutrients digestibility, blood and milk characteristics. A feeding trial was conducted for 21 days from parturition to weaning. Experimental diets were supplied for 1 week before the parturition day and throughout the experimental period. Dietary treatments included: 1) CON (basal diet), 2) CFP (basal diet added $0.5 \%$ coconut fat powder) and 3) CFH (basal diet added 0.5\% coconut fat power containing husk). An average daily feed intake was significantly improved in CFP and CFH treatments compared with CON treatment $(\mathrm{P}<0.05)$. A backfat loss was significantly lower in CFP and $\mathrm{CFH}$ treatments than $\mathrm{CON}$ treatment $(\mathrm{P}<0.05)$. Compared with $\mathrm{CON}$ treatment, final body weight, weight gain and average daily gain in piglet were significantly increased in CFP and CFH treatments $(\mathrm{P}<0.05)$. Red blood cell was significantly increased in $\mathrm{CFH}$ treatment compared with others $(\mathrm{P}<0.05)$. White blood cell at the final period and lymphocyte at the final period and differences were significantly increased in sows fed coconut fat powder diet $(\mathrm{P}<0.05)$. At the final period, a milk fat concentration was significantly improved in CFP and $\mathrm{CFH}$ treatments compared with CON treatment $(\mathrm{P}<0.05)$. A milk protein concentration was significantly higher in CFP treatment than CFH treatment at the initial period $(\mathrm{P}<0.05)$ and was significantly lower in CFP and $\mathrm{CFH}$ treatments than CON treatment at the final period $(\mathrm{P}<0.05)$. And a milk lactose concentration at the initial period was significantly increased in $\mathrm{CFH}$ treatment compared with CON and CFP treatments $(\mathrm{P}<0.05)$. On diarrhea rate in piglet, three piglet occurred in CON treatment. In conclusion, dietary fat source from coconut supplementation improved feed intake, backfat loss, RBC, WBC and lymphocyte in sow and weight gain in piglet.
\end{abstract}

(Key words : Coconut, Performance, Nutrient digestibility, Blood and milk characteristics, Sow)

$$
\text { I. 서 론 }
$$

양돈산업에 있어 생산성을 높이는데 중요한 부분을 차지하는 요소 중에 하나가 모돈의 생 산성이며, 특히 여름철에는 사료섭취량의 저하
로 인해 에너지 함량이 높은 사료를 급여해야 한다. Schoenherr 등(1989a, b)은 $20^{\circ} \mathrm{C}$ 와 $32^{\circ} \mathrm{C}$ 에 서 모돈에게 지방원을 급여하였을 때 섬유소원 을 급여하였을 때보다 에너지 이용률이 $20^{\circ} \mathrm{C}$ 와 $32^{\circ} \mathrm{C}$ 에서 가소화에너지는 $4.34 \mathrm{Mcal} / \mathrm{kg}$ 과 4.35

Corresponding author : In Ho Kim, Dept. of Animal Resource \& Science, Dankook University \#29 Anseodong, Cheonan, Choongnam 330-714, Korea

Tel : 041-550-3652, Fax : 041-550-3604, E-mail : inhokim@dankook.ac.kr 
$\mathrm{Mcal} / \mathrm{kg}$ 이였으며 대사에너지는 $4.20 \mathrm{Mcal} / \mathrm{kg}$ 과 $4.10 \mathrm{Mcal} / \mathrm{kg}$ 으로 각각 향상된 결과를 보였다고 하였다. 또한, 사료섭취량에서는 섬유소원, 탄 수화물원 및 지방원 간에 유의적 차이는 없었 으나 대사에너지가에서는 지방원을 급여한 처 리구가 $20^{\circ} \mathrm{C}$ 와 $32^{\circ} \mathrm{C}$ 에서 각각 $20.0 \mathrm{Mcal} / \mathrm{d}$ 와 $13.0 \mathrm{Mcal} / \mathrm{d}$ 로 다른 처리구와 비교하여 유의적 으로 향상되었다고 보고하였다. 또한, 겨울보다 는 특히 여름에 포유모돈 사료내 지방의 첨가 는 재귀발정일을 단축시킨다는 보고도 있다 (Cox et al., 1983; Shurson et al., 1986).

모돈의 생산성과 관련하여 중요한 또 하나의 요소는 포유자돈의 생산성이며 이 또한 모돈의 생산성과 연관된 부분이다. 포유기 때 모돈의 영양상태가 고르지 못하면 비유성적이 좋지 못 하고 그로 인해 모유에 의존해 성장하는 포유 자돈의 성장에도 좋지 못한 영향을 미친다. 포 유모돈 사료내 지방원을 급여하였을 때 포유자 돈 성적에 관한 연구들도 다수 이루어졌는데 포유기간 동안 모돈사료내 지방원을 급여하였 을 때 이유시 자돈의 체중이 증가하였다고 보 고한 연구(Boyd et al., 1982; Shurson et al., 1986)도 있지만 자돈의 증체량에는 영향을 미 치지 않는다는 보고(Kruse et al., 1977; Coffey et al., 1987)도 있다. 또한, 포유모돈 사료내 지 방원 또는 1,3-butanediol을 첨가급여하였을 때 이유시까지의 자돈 생존율을 증가시킨다는 보 고(Stahly et al., 1985; Libal et al., 1987)도 있는 반면, 자돈 생존율에는 영향을 미치지 않는다 는 보고(Pettigrew, 1981; Stahly et al., 1981)도 있어 좀 더 많은 연구가 필요하다고 본다.

코코넛 오일에 있어서 Cera 등(1989, 1990)은 이유자돈 사료내 코코넛 오일 첨가는 성장률과 사료섭취량, 사료요구율 및 소화율을 향상시킨 다고 보고하였으며 Mahan (1991)은 이유자돈 사료내 코코넛 오일의 첨가가 증체량과 사료효 율을 향상시킨다고 보고하였다. 또한, 조 등 (2007)은 이유자돈 사료내 코코넛 오일 첨가는 사료효율과 지방소화율을 개선시킨다고 보고하 였다.

이에 본 연구에서는 코코넛 속 분말지방과 껍질을 포함한 코코넛 분말지방의 첨가가 포유
모돈의 생산성, 영양소 소화율, 혈액 및 돈유성 상에 미치는 효과에 대해 알아보고자 시험을 실시하였다.

\section{ㅍ. 재료 및 방법}

\section{1. 시험동물 및 시험설계}

모돈 (Landrace $\times$ Yorkshire)은 평균 3.9산차(초 산돈 4두사용)였으며 3처리, 처리당 10 두씩 포 유모돈 30 두를 공시하였으며 분만 일주일 전부 터 시험사료를 급여하였고 분만 후부터 이유시 까지 21일간 사양시험을 실시하였다. 시험설계 는 1) $\mathrm{CON}$ (basal diet), 2) $\mathrm{CFP}$ (basal diet added $0.5 \%$ coconut fat powder) 吕 3) $\mathrm{CFH}$ (basal diet added $0.5 \%$ coconut fat powder containing husk) 로 하였으며, coconut fat powder는 코코넛의 속 부분 중 하얀색 부분만을 가공한 것이며 husk 를 함유한 coconut fat powder는 코코넛 속 하 얀 부분 안쪽에 섬유소를 함유한 부분과 함께 가공한 것으로 husk를 함유한 coconut fat powder가 coconut fat powder에 비해 섬유소 함 량이 더욱 높다. 분만 후 자돈은 모돈에 복당 10 마리씩 균일하게 배치하였다.

\section{2. 시험사료과 사양관리}

시험사료는 NRC(1998) 요구량에 따라 배합 한 옥수수-대두박 위주의 사료(Table 1)로서 아침과 저녁 두 번으로 나누어 자유채식토록 하였으며 물은 자동급수기를 이용하여 자유로 이 섭취할 수 있도록 하였다. 또한, 시험사료에 첨가된 코코넛 분말지방의 일반성분 조성은 Table 2에 나타내었다.

\section{3. 조사항목 및 방법}

\section{(1) 포유모돈 등지방두께}

포유모돈의 등지방두께는 개시시와 종료시에

Digital backfat indicator(Renco lean-meter, USA) 를 이용하여 1 번째 및 10 번째 늑골과 요추인 3 개 부위의 정중선으로부터 $5 \mathrm{~cm}$ 떨어진 곳을 
Table 1. Feed formula and chemical composition for experiment

\begin{tabular}{|c|c|c|c|}
\hline Ingredient, \% & $\mathrm{CON}^{1)}$ & $\mathrm{CFP}^{1)}$ & $\mathrm{CFH}^{1)}$ \\
\hline Corn & 55.659 & 56.693 & 56.849 \\
\hline Soybean meal & 31.876 & 32.113 & 32.139 \\
\hline Tallow & 3.634 & 3.134 & 3.134 \\
\hline Cconut fat powder & - & 0.500 & - \\
\hline Coconut fat powder containing husk & - & - & 0.500 \\
\hline Wheat bran & 5.000 & 4.716 & 4.534 \\
\hline Rice bran & 1.000 & - & - \\
\hline Limestone & 0.987 & 0.916 & 0.911 \\
\hline Calcium phosphate & 1.344 & 1.427 & 1.434 \\
\hline Salt & 0.300 & 0.300 & 0.300 \\
\hline Vitamin premix ${ }^{2)}$ & 0.200 & 0.200 & 0.200 \\
\hline Total & 100.000 & 100.000 & 100.000 \\
\hline \multicolumn{4}{|l|}{ Chemical composition ${ }^{3)}$} \\
\hline ME (kcal/kg) & 3,350 & 3,350 & 3,350 \\
\hline Crude protein, \% & 19.10 & 19.13 & 19.12 \\
\hline Calcium, \% & 0.90 & 0.90 & 0.90 \\
\hline Phosphorus, \% & 0.70 & 0.70 & 0.70 \\
\hline Lysine, \% & 1.10 & 1.10 & 1.10 \\
\hline \multicolumn{4}{|c|}{$\begin{array}{l}\text { 1) CON, basal diet; CFP, basal diet added } 0.5 \% \text { coconut fat powder; CFH, basal diet added } 0.5 \% \text { coconut fat } \\
\text { powder containing husk. } \\
\text { 2) Supplied per kg diet: vitamin A, } 11,025 \mathrm{IU} \text {; vitamin D3, } 1,103 \mathrm{IU} \text {; vitamin E, } 44 \mathrm{IU} \text {; vitamin K(menadion } \\
\text { bisulfate complex), } 44 \mathrm{mg} \text {; liboflavin, } 8.3 \mathrm{mg} \text {; niacin, } 50 \mathrm{mg} \text {;-pantothenic acid(as d-calcium pantothenate), } 29 \\
\text { mg; Choine, } 166 \mathrm{mg} \text {; Mn, } 12 \mathrm{mg} \text { I, } 0.3 \mathrm{mg} \text {; Co, } 1.0 \mathrm{mg} \text { and Se, } 0.3 \mathrm{mg} \text {. } \\
\text { 3) Calculated value. }\end{array}$} \\
\hline
\end{tabular}

측정하여 세 개의 측정값의 평균치를 이용하였 다.

(2) 포유모돈의 영양소 소화율 및 분내 수분 함량

포유모돈에서의 영양소 소화율을 측정하기 위하여 표시물로서 산화크롬을 사료내 $0.2 \%$ 첨 가하여 시험종료 7일전부터 급여하였으며 시험 종료일 항문마사지법으로 분을 채취하였다. 채 취한 분은 $70^{\circ} \mathrm{C}$ 에서 24 시간 건조시킨 후 분내 수분함량 계산에 이용하였으며 분내 수분함량 계산 후 분을 분쇄하여 영양소 소화율 분석에
이용하였다. 사료의 일반성분과 표시물로 혼합 된 $\mathrm{Cr}$ 은 $\mathrm{AOAC(1990)}$ 에 제시된 방법에 의해 분 석하였다.

\section{(3) 포유모돈의 혈액성상}

포유모돈의 혈액성상은 시험 개시시와 종료 시에 모든 모돈의 이정맥(耳靜脈)에서 K3 EDTA Vacuum tube(Becton Dickinson Vacutainer Systems, Franklin Lakes, NJ)에 2ml, Vacuum tube(Becton Dickinson Vacutainer Systems, Franklin Lakes, $\mathrm{NJ}$ )에 $5 \mathrm{ml}$ 씩 각각 채취하여 혈액성상 검사에 이용하였다. 혈액성상 검사는 자동 혈액분석기 
Table 2. Composition of additives (Amount per 100g)

\begin{tabular}{lcc}
\hline Item & CFP $^{1)}$ & CFH $^{1)}$ \\
\hline \hline Calories, kcal & 700 & 741 \\
Total Carbohydrates, g & 24 & 20 \\
Protein, g & 9 & 7 \\
Total fat, g & & \\
$\quad$ Saturated & 62.4 & 62.4 \\
$\quad$ Mono unsaturated & 0.6 & 3.8 \\
$\quad$ Poly unsaturated & 1.9 & 2.0 \\
Crude Fiber, g & 3.5 & 13.2 \\
Calcium, mg & 20 & 72 \\
Sodium, mg & Traces & 21 \\
\hline
\end{tabular}

1) $\mathrm{CFP}$, coconut fat powder; $\mathrm{CFH}$, coconut fat powder containing husk.

(ADVID 120, Bayer, USA)를 이용하여 WBC (white blood cell), RBC(red blood cell)와 Lymphocyte를 측정하였다. 또한, 혈청생화학 검 사는 채취한 $5 \mathrm{ml}$ 의 혈액을 $4^{\circ} \mathrm{C}$ 에서 $2,000 \times \mathrm{g}$ 로 30 분간 원심분리하여 얻은 혈청을 분석에 이용 하였다. 혈청생화학적 검사는 자동 생화학 분 석기(HITACHI 747, Japan)를 이용하여 Total protein, Albumin 및 IgG 함량을 측정하였다.

\section{(4) 포유모돈의 모유성상}

포유모돈의 모유성상은 시험 개시시에는 분 만직후, 종료시에는 모돈이 자돈의 포유를 허 락하는 때에 자돈을 격리시켜 모든 모돈에서 $50 \mathrm{ml}$ 씩 채취한 후 Lactoscope(Petta. Ins. Co., Netherland)를 이용하여 일반성분 분석에 이용 하였다.

\section{(5) 포유모돈의 사료섭취량}

포유모돈의 사료섭취량은 총 시험기간 동안 의 섭취량에서 종료시 잔량을 감하여 계산하였 다.

\section{(6) 포유모돈의 직장온도 변화}

포유모돈의 직장온도 변화는 시험 개시일부 터 종료일까지 3일 간격으로 직장온도계(TES 1311, E\&E Process Instrument, Taiwan)를 이용
하여 측정하였다.

\section{(7) 포유자돈 일당증체량}

포유자돈의 일당증체량은 개시시(분만시)와 종료시(이유시)에 각각 측정하였다.

(8) 포유자돈 생존율

포유자돈의 생존율은 개시시부터 매일 자돈 의 총 마리수를 확인하여 계산에 이용하였다.

\section{(9) 포유자돈의 설사발생}

포유자돈의 설사발생정도는 시험 개시일부터 종료일까지 매일 자돈의 항문상태를 점검하여 설사를 하는 자돈의 마릿수를 확인하였으며 0 (normal feces), 1 (soft feces), 2 (mild diarrhea), 3 (severe diarrhea)의 점수로 설사지수를 계산하였 다.

\section{4. 통계처리}

모든자료는 SAS(1996)의 General Linear Model Procedure를 이용하여 분산분석을 실시하였으며 pen을 experimental unit으로 하였다. 처리평균간 의 유의성 검정은 Duncan의 다중검정법(1955) 을 이용하였다.

\section{III. 결과 및 고찰}

포유모돈에 있어 코코넛 분말지방 첨가가 포 유모돈 및 포유자돈에 미치는 영향은 Table 3 에 나타내었다. 포유모돈의 섭취량에 있어서는 $\mathrm{CFP}$ 와 $\mathrm{CFH}$ 처리구가 $\mathrm{CON}$ 처리구와 비교하여 유의적으로 높았다 $(\mathrm{P}<0.05)$. Chariotte와 Viggo (2004)가 포유모돈 사료내 동물성 지방, 채종유, 어유, 코코넛유, 팜유 및 해바라기유(sunflower oil)을 첨가. 급여하였을 때 코코넛유를 제외한 다른 지방원에서 일당에너지섭취량을 향상시켰 다는 보고는 본 시험결과와 상이하였다.

포유모돈의 등지방 변화에 있어서는 $\mathrm{CFP}$ 와 $\mathrm{CFH}$ 처리구가 $\mathrm{CON}$ 처리구와 비교하여 유의적 으로 낮았다 $(\mathrm{P}<0.05)$. Creswell과 Brooks (1971) 는 코코넛 오일과 코코넛박의 첨가수준을 다르 게 하여 육성돈에게 급여하였을 때 등지방두께 
Table 3. Effects of dietary coconut fat powder supplementation on performance in lactating sow and piglet

\begin{tabular}{|c|c|c|c|c|}
\hline Items & $\mathrm{CON}^{1)}$ & $\mathrm{CFP}^{1)}$ & $\mathrm{CFH}^{1)}$ & $\mathrm{SE}^{2)}$ \\
\hline The number of sows & 10 & 10 & 10 & \\
\hline \multicolumn{5}{|l|}{ Sow performance } \\
\hline ADFI, kg & $4.67^{\mathrm{b}}$ & $5.30^{\mathrm{a}}$ & $5.25^{\mathrm{a}}$ & 0.16 \\
\hline \multicolumn{5}{|l|}{ Backfat thickness, mm } \\
\hline Initial (d 0: farrowing) & 31.33 & 33.00 & 31.61 & 2.21 \\
\hline Final (d 21: weaning) & 26.76 & 30.19 & 29.11 & 2.19 \\
\hline Backfat loss & $-4.56^{\mathrm{b}}$ & $-2.81^{\mathrm{a}}$ & $-2.49^{\mathrm{a}}$ & 0.47 \\
\hline \multicolumn{5}{|l|}{ Digestibility } \\
\hline Dry matter & 81.60 & 81.54 & 82.01 & 0.87 \\
\hline $\mathrm{N}$ & 81.07 & 81.69 & 80.70 & 1.38 \\
\hline Moisture content in feces & 56.54 & 58.79 & 58.14 & 1.89 \\
\hline Return to estrus, day & 5.50 & 5.50 & 5.50 & 0.24 \\
\hline \multicolumn{5}{|l|}{ Piglet performance } \\
\hline Initial piglet BW & 1.59 & 1.52 & 1.55 & 0.07 \\
\hline Final piglet BW & $6.26^{\mathrm{b}}$ & $6.98^{\mathrm{a}}$ & $6.86^{\mathrm{a}}$ & 0.14 \\
\hline Weight gain & $4.66^{\mathrm{b}}$ & $5.46^{\mathrm{a}}$ & $5.31^{\mathrm{a}}$ & 0.17 \\
\hline $\mathrm{ADG}$ & $0.22^{\mathrm{b}}$ & $0.26^{\mathrm{a}}$ & $0.25^{\mathrm{a}}$ & 0.01 \\
\hline Survival rate & 99.68 & 99.66 & 99.78 & 0.13 \\
\hline
\end{tabular}

에서 유의적 차이를 보이지 않았다고 하였으며 Stahly 등(1981)이 모돈 사료내 Oleic acid와 Linoleic acid(safflower oil)를 첨가급여하였을 때 등지방 두께에서 유의적인 차이를 보이지 않았다고 보 고하여 본 연구와 상이하였다. 코코넛 내 지방 산은 중쇄지방산을 다량 함유하고 있어 장쇄지 방산에 비해 장에서의 흡수 및 간에서의 산화 가 빠르며(Bach et al., 1977; Bremer, 1980; Friedman and Nylund, 1980; Cera et al., 1989) 이렇게 장에서 흡수되거나 간에서 산화된 지방 산은 지단백형태로 운반되어 지방조직에 축적 된다고 알려져 있다. 본 시험에서 코코넛 첨가 구가 코코넛 미첨가구에 비해 등지방 손실이
적은 것은 코코넛 내 중쇄지방산의 함량이 높 아 나타난 결과일 것이라 사료되며 보다 추가 적인 연구가 필요하다고 본다.

포유모돈의 건물과 질소 소화율 및 분내 수 분함량, 재귀발정일에 있어서는 처리구간에 유 의적인 차이를 보이지 않았다( $\mathrm{P}>0.05)$. 본 연구 에서 사용한 공시동물은 포유모돈이지만 조 등 (2007)은 이유자돈 사료내 코코넛 오일을 첨가 급여하였을 때 건물과 질소 소화율에서 처리구 간 유의적인 차이를 보이지 않았다고 보고하여 본 연구와 일치하였으나 Cera 등(1989)이 이유 자돈 사료내 코코넛 오일을 첨가급여하였을 때 외관상 질소 소화율에서 코코넛 오일 첨가구가 
유의적으로 높았다고 보고하여 본 연구와 상이 하였다.

포유자돈의 종료시 체중, 증체량 및 일당증 체량에 있어서는 $\mathrm{CFP}$ 와 $\mathrm{CFH}$ 처리구가 $\mathrm{CON}$ 처리구와 비교하여 유의적으로 높았다 $(\mathrm{P}<0.05)$. Creswell과 Brooks (1971)가 코코넛 오일과 코코 넛박의 첨가수준을 다르게 하여 육성돈에게 급 여하였을 때 일당증체량에서 코코넛 오일과 코 코넛박 미첨가구가 첨가구와 비교하여 유의적
으로 낮았다는 보고와 일치하였으나 Mahan (1991), 조 등(2007) 및 Cera 등(1989)이 이유자 돈 사료내 코코넛 오일을 첨가급여하였을 때 증체량과 일당증체량에서 처리구간에 유의적인 차이를 보이지 않았다는 보고와는 상이하였다.

포유자돈의 생존율에 있어서는 처리구간에 유의적인 차이를 보이지 않았다( $\mathrm{P}>0.05)$. Kepler 등(1982)은 임신 및 포유모돈 사료내 지방원으 로써 sunflower seed를 첨가하였을 때 자돈의

Table 4. Effects of dietary fat source from coconut supplementation on blood characteristics in lactating sow

\begin{tabular}{|c|c|c|c|c|}
\hline Items & $\mathrm{CON}^{1)}$ & $\mathrm{CFP}^{1)}$ & $\mathrm{CFH}^{1)}$ & $\mathrm{SE}^{2)}$ \\
\hline \multicolumn{5}{|l|}{ T.Protein, g/dL } \\
\hline Initial (d 0 : farrowing) & 6.50 & 6.63 & 6.36 & 0.13 \\
\hline Final (d 21 : weaning) & 7.53 & 7.73 & 7.73 & 0.23 \\
\hline Difference & 1.03 & 1.10 & 1.37 & 0.19 \\
\hline \multicolumn{5}{|l|}{ Albumin, g/dL } \\
\hline Initial (d 0 : farrowing) & 3.83 & 3.90 & 3.90 & 0.08 \\
\hline Final (d 21 : weaning) & 4.33 & 4.33 & 4.30 & 0.06 \\
\hline Difference & 0.50 & 0.43 & 0.40 & 0.12 \\
\hline \multicolumn{5}{|l|}{ IgG, mg/dL } \\
\hline Initial (d 0 : farrowing) & 573.00 & 518.33 & 518.00 & 29.55 \\
\hline Final (d 21 : weaning) & 810.66 & 835.00 & 809.66 & 58.51 \\
\hline Difference & 237.66 & 316.67 & 291.66 & 49.19 \\
\hline \multicolumn{5}{|l|}{ RBC, \% } \\
\hline Initial (d 0 : farrowing) & $4.38^{\mathrm{b}}$ & $4.36^{\mathrm{b}}$ & $5.13^{\mathrm{a}}$ & 0.12 \\
\hline Final (d 21 : weaning) & 5.95 & 5.86 & 6.21 & 0.18 \\
\hline Difference & 1.57 & 1.50 & 1.08 & 0.19 \\
\hline \multicolumn{5}{|l|}{ WBC, \% } \\
\hline Initial (d 0 : farrowing) & 10.31 & 11.84 & 12.60 & 2.87 \\
\hline Final (d 21 : weaning) & $14.85^{\mathrm{ab}}$ & $10.56^{\mathrm{b}}$ & $15.75^{\mathrm{a}}$ & 1.11 \\
\hline Difference & 4.54 & -1.28 & 3.15 & 2.13 \\
\hline \multicolumn{5}{|l|}{ Lymphocyte, \% } \\
\hline Initial (d 0 : farrowing) & 34.33 & 34.00 & 33.66 & 2.98 \\
\hline Final (d 21 : weaning) & $39.66^{\mathrm{b}}$ & $53.66^{\mathrm{a}}$ & $51.33^{\mathrm{a}}$ & 2.45 \\
\hline Difference & $5.33^{\mathrm{b}}$ & $19.66^{\mathrm{a}}$ & $17.67^{\mathrm{a}}$ & 1.71 \\
\hline
\end{tabular}


생존율에서 유의적인 차이를 보이지 않았다고 하였으며 Shurson과 Irvin(1992) 또한 포유모돈 사료내 대두유를 첨가하였을 때 자돈의 생존율 에서 유의적인 차이를 보이지 않았다고 보고하 였다. Pettigrew (1981)는 review 연구에서 총 초 산돈 사료내 지방원 첨가연구 중 31 개의 연구 에서 생존율이 높았으며 18 개의 연구에서는 오 히려 낮았다고 보고하여 모돈에 지방원의 첨가 에 따른 포유자돈의 생존율에 관한 연구가 좀 더 필요하다고 사료된다.

포유모돈에 있어 코코넛 분말지방 첨가가 포 유모돈의 혈액성상에 미치는 영향은 Table 4에 나타내었다. Total protein과 albumin, IgG 함량 에서는 처리구간에 유의적인 차이를 보이지 않 았지만(P>0.05) red blood cell 함량에서는 개시 시에 $\mathrm{CFH}$ 처리구가 $\mathrm{CON}$ 과 $\mathrm{CFP}$ 처리구와 비 교하여 유의적으로 높았고 $(\mathrm{P}<0.05)$ white blood cell 함량에서는 종료시에 $\mathrm{CFH}$ 처리구가 $\mathrm{CFP}$ 처리구와 비교하여 유의적으로 높았으며 $(\mathrm{P}<$ 0.05) lymphocyte 함량에서는 종료시와 변화량 에서 $\mathrm{CFP}$ 와 $\mathrm{CFH}$ 처리구가 $\mathrm{CON}$ 처리구와 비 교하여 유의적으로 높았다 $(\mathrm{P}<0.05)$. Brian 등 (2004)의 연구에 의하면 돼지에 있어 병원체가
침입한 경우 지방조직을 형성하는 지방세포로 부터 호르몬과 유사한 물질이 생성되면서 면역 반응이 조절된다고 하였는데 지방세포가 감염 에 대항하는 반응을 나타내기 위해서는 interferon- $\gamma$ 가 필요하며 interferon- $\gamma$ 에 지방세포가 노출되면 면역반응 및 염증반응의 매개체 역할 을 하는 사이토카인(cytokine)이 생성된다고 하 였다. 본 시험에서도 코코넛 분말지방을 첨가 할 경우 코코넛 분말지방 미첨가구에 비해 보 다 많은 지방축적을 가져왔을 것으로 생각되어 지며 이러한 지방축적이 모돈의 면역력을 높인 것이라 사료된다.

포유모돈에 있어 코코넛 분말지방 첨가가 포 유모돈의 모유성상에 미치는 영향은 Table 5에 나타내었다. 모유내 지방 함량에서는 $\mathrm{CFP}$ 와 $\mathrm{CFH}$ 처리구가 $\mathrm{CON}$ 처리구와 비교하여 유의적 으로 높았다 $(\mathrm{P}<0.05)$. 이는 앞에서 언급한 바와 같이 코코넛 내 지방의 빠른 흡수 및 분해에 의해 혈액내로의 지방 전이량이 많은 결과라 사료된다. Stahly 등(1981)은 모돈 사료내 Oleic acid와 Linolein acid(safflower oil)를 첨가급여하 였을 때 모유내 지방 함량에서 지방산 첨가구 가 유의적으로 높은 결과를 보였다고 보고하였

Table 5. Effects of dietary fat source from coconut supplementation on milk contents in lactating sow

\begin{tabular}{|c|c|c|c|c|}
\hline Items, \% & $\mathrm{CON}^{1)}$ & $\mathrm{CFP}^{1)}$ & $\mathrm{CFH}^{1)}$ & $\mathrm{SE}^{2)}$ \\
\hline \multicolumn{5}{|l|}{ Fat } \\
\hline Initial (d 0: farrowing) & 7.82 & 7.81 & 7.37 & 0.73 \\
\hline Final (d 21: weaning) & $7.07^{\mathrm{b}}$ & $8.03^{\mathrm{a}}$ & $8.05^{\mathrm{a}}$ & 0.11 \\
\hline \multicolumn{5}{|l|}{ Protein } \\
\hline Initial (d 0: farrowing) & $19.78^{\mathrm{ab}}$ & $21.40^{\mathrm{a}}$ & $17.86^{\mathrm{b}}$ & 0.69 \\
\hline Final (d 21: weaning) & $5.81^{\mathrm{a}}$ & $5.27^{\mathrm{b}}$ & $5.14^{\mathrm{b}}$ & 0.07 \\
\hline \multicolumn{5}{|l|}{ Lactose } \\
\hline Initial (d 0: farrowing) & $1.62^{\mathrm{b}}$ & $1.87^{\mathrm{b}}$ & $2.48^{\mathrm{a}}$ & 0.13 \\
\hline Final (d 21: weaning) & 5.74 & 5.60 & 5.83 & 0.11 \\
\hline
\end{tabular}


Table 6. Effects of dietary fat source from coconut supplementation on diarrhea index in piglet

\begin{tabular}{cccc}
\hline Items & $\mathrm{CON}^{1)}$ & $\mathrm{CFP}^{1)}$ & $\mathrm{CFH}^{1)}$ \\
\hline \hline Day & & & \\
$0 \sim 5$ & $3(0.04)$ & $0(0.00)$ & $0(0.00)$ \\
$5 \sim 10$ & $0(0.01)$ & $0(0.00)$ & $0(0.00)$ \\
$10 \sim 15$ & $0(0.01)$ & $0(0.04)$ & $0(0.02)$ \\
$15 \sim 20$ & $0(0.00)$ & $0(0.10)$ & $0(0.00)$ \\
\hline
\end{tabular}

${ }^{1)} \mathrm{CON}$, basal diet; CFP, basal diet added $0.5 \%$ coconut fat powder; CFH, basal diet added $0.5 \%$ coconut fat powder containing husk.

으며 Shurson과 Irvin(1992)은 포유모돈 사료내 대두유 첨가시 유의적으로 높은 함량을 보였다 고 보고하였다. 그 외 다수 연구에서도 포유모 돈 사료내에 지방을 첨가했을 때 모유내 지방 함량을 증가시킨다고 하였다(Coffey et al., 1982; Moser, 1985). 모유내 단백질 함량에서는 개시 시에 $\mathrm{CFP}$ 처리구가 $\mathrm{CFH}$ 처리구와 비교하여 유의적으로 높았으며 $(\mathrm{P}<0.05)$ 종료시에는 $\mathrm{CON}$ 처리구가 $\mathrm{CFP}$ 와 $\mathrm{CFH}$ 처리구와 비교하여 유의 적으로 높았다 $(\mathrm{P}<0.05)$. Lactose 함량에서는 $\mathrm{CFH}$ 처리구가 $\mathrm{CON}$ 과 $\mathrm{CFP}$ 처리구와 비교하여 유의적으로 높았다 $(\mathrm{P}<0.05)$.

포유모돈에 있어 코코넛 분말지방 첨가가 포 유자돈의 설사지수에 미치는 영향은 Table 6에 나타내었다. 설사발생에 있어서 $0 \sim 5$ 일째에 $\mathrm{CON}$ 처리구에서 3 마리가 발생하였으나 초기 포유자 돈의 장관발달이 아직 완전히 이루어지지 않아 발생한 것으로 사료되며 5 20일까지는 모든 처 리구에서 설사발생이 일어나지 않았다.

포유모돈에 있어 코코넛 분말지방 첨가가 포 유모돈의 직장온도에 미치는 영향은 Fig. 1에 나타내었다. 세 처리 모두에서 유사한 온도변 화를 보였다.

본 시험결과 포유모돈에 있어 코코넛 분말지 방 첨가는 포유모돈에 있어서는 사료섭취량 증 가와 등지방 손실감소를 보이며 혈액 내 RBC, WBC, lymphocyte를 향상시켰다. 또한, 포유자 돈에 있어서는 증체량을 개선시키는 것으로 사 료된다.

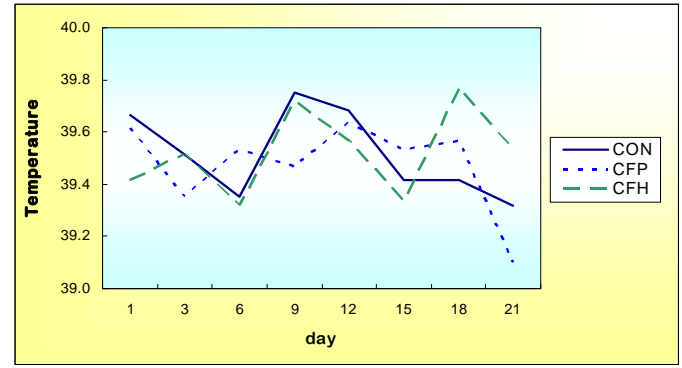

Fig. 1. Effects of dietary coconut fat powder supplementation on rectal temperature in lactating sow.

IV. 요 약

본 시험은 코코넛 분말지방 첨가가 포유모돈 의 생산성, 영양소 소화율, 혈액 및 돈유성상에 미치는 효과에 미치는 효과를 알아보고자 실시 하였다. 모돈은 건강상태 및 산차를 고려하여 3 처리, 처리당 10 두씩 포유모돈 30 두를 공시하 였으며 분만 일주일 전부터 시험사료를 급여하 였고 분만 후부터 이유시까지 21일간 사양시험 을 실시하였다. 시험설계는 1) CON(basal diet), 2) CFP(basal diet added $0.5 \%$ coconut fat powder) 및 3) $\mathrm{CFH}$ (basal diet added $0.5 \%$ coconut fat powder containing husk)로 하였으며, 분만 후 자돈은 모돈에 복당 10 마리씩 균일하게 배치하 였다. 포유모돈의 섭취량에 있어서는 $\mathrm{CFP}$ 와 $\mathrm{CFH}$ 처리구가 $\mathrm{CON}$ 처리구와 비교하여 유의적 으로 높았다 $(\mathrm{P}<0.05)$. 포유모돈의 등지방 변화 에 있어서는 $\mathrm{CFP}$ 와 $\mathrm{CFH}$ 처리구가 $\mathrm{CON}$ 처리 
구와 비교하여 유의적으로 낮았다 $(\mathrm{P}<0.05)$. 포 유자돈의 종료시 체중, 증체량 및 일당증체량 에 있어서는 $\mathrm{CFP}$ 와 $\mathrm{CFH}$ 처리구가 $\mathrm{CON}$ 처리 구와 비교하여 유의적으로 높았다 $(\mathrm{P}<0.05)$. Red blood cell 함량에서는 개시시에 $\mathrm{CFH}$ 처리구가 $\mathrm{CON}$ 과 $\mathrm{CFP}$ 처리구와 비교하여 유의적으로 높 았고 $(\mathrm{P}<0.05)$ white blood cell 함량에서는 종료 시에 $\mathrm{CFH}$ 처리구가 $\mathrm{CFP}$ 처리구와 비교하여 유의적으로 높았으며 $(\mathrm{P}<0.05)$ lymphocyte 함량 에서는 종료시와 변화량에서 $\mathrm{CFP}$ 와 $\mathrm{CFH}$ 처리 구가 $\mathrm{CON}$ 처리구와 비교하여 유의적으로 높았 다 $(\mathrm{P}<0.05)$. 모유내 지방 함량에서는 $\mathrm{CFP}$ 와 $\mathrm{CFH}$ 처리구가 $\mathrm{CON}$ 처리구와 비교하여 유의적 으로 높았다 $(\mathrm{P}<0.05)$. 모유내 단백질 함량에서 는 개시시에 $\mathrm{CFP}$ 처리구가 $\mathrm{CFH}$ 처리구와 비 교하여 유의적으로 높았으며 $(\mathrm{P}<0.05)$ 종료시에 는 $\mathrm{CON}$ 처리구가 $\mathrm{CFP}$ 와 $\mathrm{CFH}$ 처리구와 비교 하여 유의적으로 높았다 $(\mathrm{P}<0.05)$. 또한, Lactose 함량에서는 $\mathrm{CFH}$ 처리구가 $\mathrm{CON}$ 과 $\mathrm{CFP}$ 처리구 와 비교하여 유의적으로 높았다 $(\mathrm{P}<0.05)$. 포유 자돈에서의 설사발생에 있어서는 $0 \sim 5$ 일째에 $\mathrm{CON}$ 처리구에서 세 마리가 발생하였다. 본 시 험결과 포유모돈에 있어 코코넛 분말지방 첨가 는 포유모돈에 있어서는 사료섭취량 증가와 등 지방 손실감소를 보이며 혈액 내 $\mathrm{RBC}, \mathrm{WBC}$, lymphocyte를 향상시켰다. 또한, 포유자돈에 있 어서는 증체량을 개선시키는 것으로 사료된다.

(주요어 : 코코넛, 생산성, 영양소 소화율, 혈액 및 돈유성상, 모돈)

\section{$\mathrm{V}$. 인 용 문 헌}

1. AOAC. 1990. Official Methods of Analysis. $15^{\text {th }}$ ed. Association of Official Analytical Chemists. Arlington, VA, USA.

2. Bach, A., Schirardin, H., Bauer, M. and Weryha, A. 1977. Ketogenic response to medium chain triglyceride load in the rat. J. Nutr. 107:18631870.

3. Bremer, J. 1980. Carnitine and its role in fatty acid metabolism. Trends Biochem. Sci. 2:207-246.

4. Brian, J. Prendergast, Stack D. Bilbo and Randy
J. Nelson. 2004. Photoperiod controls the induction, retention, and retrieval of antigenspecific immunological memory. Am. J. Physiol. Regul. Intergr. Comp. Physoil. 286:54-60.

5. Cera, K. R., Mahan, D. C. and Reinhart, G. A. 1989. Apparent fat digestibilities and performance responses of postweaning swine fed diets supplemented with coconut oil, corn oil or tallow. J. Anim. Sci. 67:2040-2047.

6. Charlotte L. and Viggo D. 2004. Lactational dietary fat levels and sources influence milk composition and performance of sows and their progeny. Livestock Production Sci. 91:95-105.

7. Cera, K. R., Mahan, D. C. and Reinhart, G. A. 1989. Apparent fat digestibilities and performance responses of postweaning swine fed diets supplemented with coconut oil, corn oil or tallow. J. Anim. Sci. 67:2040-2047.

8. Coffey, M. T., Seerley, R. W. and Mabry, J. W. 1982. The effect of source of supplemental dietary energy on sow milk yield, milk composition and litter performance. J. Anim. Sci. 55:1388-1394.

9. Creswell, D. C. and Brooks, C. C. 1971. Effect of coconut meal on coturnix quail and of coconut meal and coconut oil on performance, carcass measurements and fat composition in swine. J. Anim. Sci. 33:370-375.

10. Duncan, D. B. 1955. Multiple range. Biometrics. 11:1-42.

11. Friedman, H. I. and Nylund, B. 1980. Intestinal fat digestion, absorption and transport. Am. J. Clin. Nutr. 33:1108-1139.

12. Kelper, M., Libal, G. W. and Wahlstrom, R. C. 1982. Sunflower seeds as a fat source in sow gestation and lactation diets. J. Anim. Sci. 55: 1082-1086.

13. Mahan, D. C. 1991. Efficacy of initial postweaning diet and supplemental coconut oil or soybean oil for weanling swine. J. Anim. Sci. 69: 1397-1402.

14. Moser, B. D. 1985. The use of fat in sow diet. In: Cole D. J. A. and Haresign, W. (Ed.) Recent 
Developments in pig nutrition. pp.201-210. Butterworths, London.

15. NRC. 1998. Nutrient requirement of pigs(10th Ed.) National Research Council, Academy Press. Washington, D. C.

16. Pettigrew, J. E. 1981. Supplemental dietary fat for peripartal sows: A review. J. Anim. Sci. 53:107117.

17. SAS. 1996. SAS user's guide. Release 6.12 edition. SAS Institute. Inc., Cary, NC.

18. Shurson, G. C. and Irvin, K. M. 1992. Effects of genetic line and supplemental dietary fat on lactation performance of duroc and landrace sows.
J. Anim. Sci. 70:2942-2949.

19. Stahly, T. S., Cromwell, G. L. and Simpson, W. S. 1981. Effects of level and source of supplemental fat in the lactation diet of sows on the performance of pigs from birth to market weight. J. Anim. Sci. 51:352-360.

20. 조진호, 김해진, 진영걸, 유종상, 민병준, 김진동, 김인호. 2007. 이유자돈에 있어 대두유, 우지 및 코코넛 오일의 첨가가 생산성, 혈청 지질변화 및 영양소 소화율에 미치는 영향. 한국동물자원과학 회지. 49(1):33-40.

(접수일자 : 2007. 10. 31. / 채택일자 : 2007. 12. 17.) 